\title{
Implementation of lean practices in the construction industry: A systematic review
}

\author{
Oluwatosin Babalola*, Eziyi O. Ibem, Isidore C. Ezema \\ Department of Architecture, Covenant University, Ota, Ogun State, Nigeria
}

\section{A R T I C L E I N F O}

\section{Keywords:}

Construction industry

Lean construction practice

Lean principles

Systematic review

\begin{abstract}
A B S T R A C T
The implementation of lean principles and approaches is gaining grounds in the construction industry globally. However, there is no clear understanding of the number and categories of lean practices implemented and the benefits associated with it in the planning, design and construction of building and infrastructure projects. This paper relied on a systematic review of published literature in Scopus, Science Direct and Google Scholar to identify and categorize the different lean practices implemented in the construction industry and the benefits derivable from them. Totally, 102 documents published between 1996 and 2018 were reviewed and their contents analyzed using descriptive statistics and content analysis. A total of 32 different lean practices categorised into design and engineering; planning and control; construction and site management; and health and safety management were identified. The review also found that the last planner system and just-in-time were the top two most implemented lean practices and about 20 different economic, social and environmental benefits were linked to the implementation of lean practices in the construction industry. This review is instructive that lean practices have good prospects for enhancing the productivity of the construction industry and achieving sustainable built environment, but a critical mass uptake and sustained implementation are required to attain these goals.
\end{abstract}

\section{Introduction}

The planning, design and construction of buildings and other physical infrastructure projects generally involve complex and fragmented activities requiring the inputs of several professionals and non-professionals resulting in cumbersome coordination requirements. Consequently, the construction industry is confronted with challenges associated with the inclusion of non-value adding activities and processes in its supply chain resulting in inefficiency and low productivity [29]; [76]. One of the key manifestations of inefficiency in the construction industry is cost overrun resulting from delays in meeting delivery timelines and material wastage [47]. revealed that cost overun takes up to $14 \%$ of project contract sum, while around $70 \%$ of all projects end up in time overrun, and about $10 \%$ of the total project material end up as material waste. Material waste has specifically been identified as having serious negative impacts on the ecosystem $[26,50,75]$. Added to this are reworks, which have been identified as key sources of waste in construction leading to both cost and time overruns $[15,64]$. These issues, among several others, have contributed to the ranking of construction activities among the leading environmentally unfriendly endeavours globally [13,52,61].
In a bid to improve the productivity and sustainability records of the construction industry, several authors [5,6,22,44,65]; Eivindson, Innvær, Kolberg, Merschbrock, and Rolfsen, 2017 [24]; have observed that construction industry stakeholders are exploring several new processes, techniques, and management practices they consider as having great potential to move the industry towards being environment friendly and less wasteful methods of project delivery. One of such practices and management principles borrowed from Toyota automobile production approach that seeks to minimize waste, maximize efforts, and guarantee value for money to clients/end users [78]; Eivindson et al., 2017 [24]; and has featured prominently in construction literature in the last few decades is the lean production approach $[7,12,19,58,80,88,92]$.

In recognition of the success of lean production approach in the manufacturing sector, and its potential applications in planning, design and construction projects [79], and [17] explained that the International Group for Lean Construction in 1993 coined the word lean construction (LC) to describe an approach to designing and carrying out construction activities to minimize waste in materials, time and efforts, with the aim of achieving maximum cost-effective value. The review of literature reveals that there is emphasis on LC as a tool for minimizing

\footnotetext{
* Corresponding author.

E-mail address: meettbabs@yahoo.com (O. Babalola).
} 
construction waste $[45,60,62,92,95]$ and meeting customers' need $[45,55,88]$. As a result, the existing literature is replete with works on the various aspects of LC (see for examples Abdullah, Abulrazak, Abubakar and Sarrazin, 2009; [3,61,88,89]. Although the existing works provide insight into the various lean tools and techniques and their potential benefits in construction, some authors [66] have observed that there is a lack of understanding of the number of existing lean construction tools and practices and their specific applications in the planning, design and construction of buildings and infrastructure projects. Although previous studies [33,41,78] have attempted to identify and classify lean tools and techniques, there appears to be very little effort to systematically identify and categorize the different lean construction practices (LCPs) and their benefits. According to authors (e.g. Refs. $[21,25,36,77,91]$, this constitutes one of the key barriers to effective implementation of LCPs tools in several countries.

It is against this background that this review paper attempted to identify and categorize the different lean practices implemented in the construction industry and the specific benefits associated with them through a systematic review of published literature. This review was guided by the following research questions:

1. How many lean construction practices (LCPs) can be identified from published literature?

2. What are the different categories of lean practices implemented in the construction industry and at what stages of construction projects were they implemented?

3. What are the benefits of the implementation of lean construction practices in the attainment of the sustainability goal as reported in the literature?

This article contributes to knowledge by identifying and categorizing the existing lean construction practices and mapping them with specific building and infrastructure planning, design, and construction activities. This categorization helps to improve understanding of the existing lean construction practices to guide industry stakeholders in decision making on their implementation. The review is also important in highlighting the benefits of LCPs and their prospects for improving the productivity and sustainability records of the construction industry towards achieving sustainable built environment.

\section{Materials and methods}

The research design adopted for this study was a systematic review of published literature. This is because firstly [38], explained that a systematic review is an important scientific research approach that can be used to appraise, summarize, and communicate the findings and implications of large quantity of research publications on a particular subject. Secondly, evidence in the literature shows that previous authors $[30,66,83]$ had adopted similar approach in their respective studies.

In carrying out the review, a-five step process of (i) formulation of research questions (ii) identification of relevant published studies (iii) evaluation of the quality of studies (iv) summarizing the evidence; and (v) interpreting the findings, adopted in previous studies [38,53,59] was followed. Specifically, the first step was the formulation of research questions to guide the review. This was followed by literature search in Scopus, Science Direct, and Google Scholar to identify the articles to be included in the review. The choice of these databases was based on the fact that they are reputed to be among the largest online databases of peer-reviewed and non-peer-reviewed materials as explained by Ref. [34].

In carrying out searches for the articles in Scopus, "lean construction" was used to identify materials with lean construction in their titles, abstracts, or keywords published between 1930 and 2018. From the search, it was found that documents related to lean construction were in the forms of research articles, lecture notes, and book chapters. In Science Direct, "lean construction" was also used and a large quantum of materials with the word 'lean' were found, while in the search in Google Scholar, patents and citations were excluded and most of the articles identified were not peer-reviewed publications. Totally, 23,194 items were found in the searches in the aforementioned online databases.

Since the review is focused on the adoption/implementation of lean practices in the construction industry, there was a need to select materials with rich contents of empirical evidence on lean implementation or adoption, lean construction practices/tools/techniques or principles. Based on this, the initial screening of the materials was done to identify articles with the aforementioned terms in their titles, abstracts, or keywords. The initial screening resulted in the identification of 245 journal articles, conference papers, book chapters, industry and research reports considered as having potential of being included in this review. The next step was the screening and sorting of the identified articles, which involved actual reading of the abstracts of each articles to determine how relevant they are to the research questions. In selecting the articles reviewed, three inclusion and exclusion criteria were used. First, the articles were selected based on their degree of relevance to the research questions using the following rating scale " 1 " for low relevance, "2" for medium relevance, and " 3 " for high relevance. Previous authors $[48,59]$ have used this evaluation scale. The relevance of each article was assessed based on their methodological rigour and findings. Consequently, all articles with contents related to case studies of the implementation of (LCPs) in building and infrastructure projects were rated " 3 " and included in the review. The second criterion used was the citations of the articles. Using this criterion, priority was given to articles with high citations. The last but not the least selection criterion adopted was the currency of the articles; and based on this, most of the articles selected for reviewed were published within the last 10 years. Using the aforementioned criteria, a total of 102 documents drawn from Scopus (51 articles), Science Direct (31 articles) and Google Scholar (20 articles, research/industry reports) were included in the review.

The selected articles were read and reviewed by the authors with the aim of identifying the LCPs mentioned in each of them, the stages of project delivery they have been implemented and the benefits associated with their implementation. The review of all the articles and analysis of their contents resulted in the generation of both quantitative and qualitative data. The former was analyzed using frequencies, percentages, and ranking, while the later were analyzed using thematic content analysis. The results are presented using tables, charts, and texts for easy understanding and drawing of conclusions.

\section{Results}

\subsection{Concept of lean construction}

Fig. 1 shows the distribution of the 23,194 items identified in the searches conducted in three online databases. Although many of the articles identified were found in all the three databases, it is evident in Fig. 1 that the largest percentage of the items are in Science Direct with

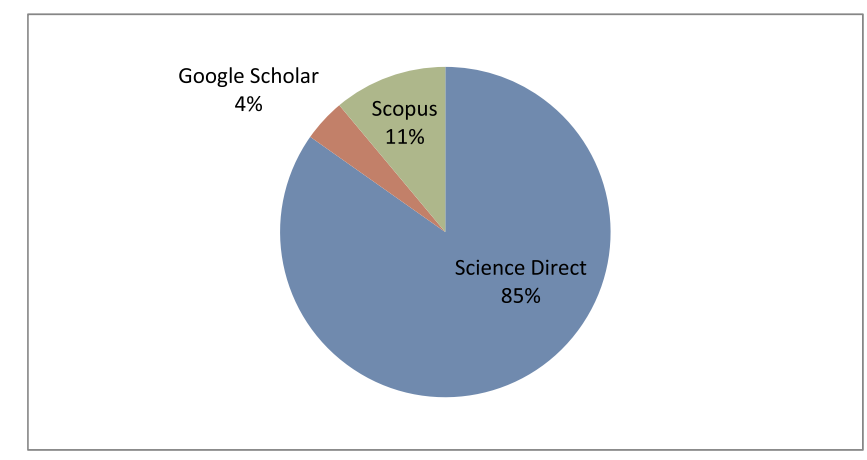

Fig. 1. Sources of materials on lean construction identified in the searches. 


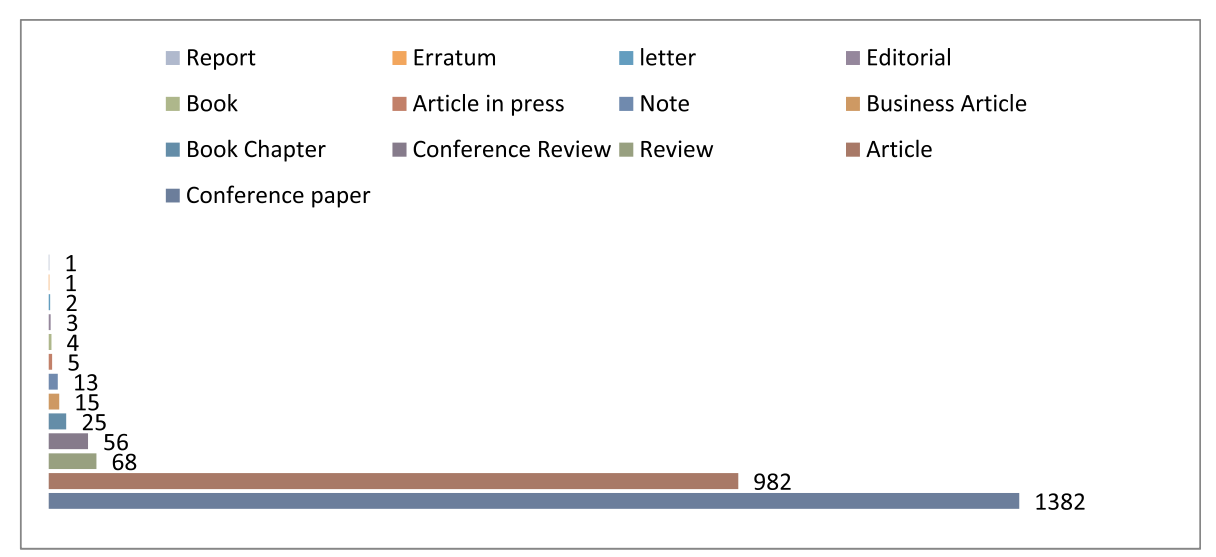

Fig. 2. Types of documents identified in Scopus.

a total of 19,661 items comprising 1214 review articles, 14, 459 research papers, 328 encyclopedia, and 3660 book chapters. Examination of the items in Science Direct revealed that every published material with the word 'lean' in its title, abstract or keywords came out in the search and most of them are on the subject of lean production generally and not lean construction, which is the subject of this review.

In Google Scholar, 963 items comprising research articles, review papers, books chapters, and books were identified. The search in Scopus, which was the database where a high majority of peer-reviewed articles were found, resulted in the identification of 2570 materials ranging from conference papers to reports as shown in Fig. 2.

From Fig. 2, it is evident 1382 (54\%), 982 (38.2\%) and 68 (3\%) of the materials found in Scopus were conference papers, research articles and review articles, respectively. It was also found that $81 \%$ of the materials were published between 2005 and 2018 in top three countries, namely, the USA, the United Kingdom, and Brazil, and in 103 outlets with the leading outlets being Lean Construction Journal. The three leading authors in this field were found to be G. Ballard; L. Koskela and D. Tommelein.

From the materials identified in the three databases the search was conducted, it is evident that there is a massive literature that conceptualizes, discusses, defines, and explains the lean thinking and production approach from various perspectives. However, there appears to a consensus in the literature $[18,19,46,97]$ indicating that the lean thinking originated from the Toyota Car Manufacturing Company as an innovative approach to achieving a substantial reduction of waste through the adoption of simpler methods of production, elimination of non-value adding, undesirable and complex activities in the production process. This informs why several authors $[12,41,78]$ have noted that the current debate on lean approach centers on the idea of doing more with less effort, material, equipment, personnel and space while focusing on what adds value to customers/clients and eliminating waste in the value chain of production. In line with this [39], cited in Ref. [30] insist that waste elimination, partnering and structuring are the three models of lean thinking; and that the original concept of lean production was based on two pillars: "Just-in-time flow (JIT) and smart automation.

In addition, it was also observed that several authors $[37,54,57,101]$ have identified the key lean principles include (i) reduction of non value-adding activities (ii) increasing consideration on customer requirement (iii) reduction in variability (iv) reduction of cycle time (v) simplification by minimizing the number of steps and parts (vi) increasing output flexibility (vii) increasing process transparency (viii) focus on control of the complete process (ix) building continuous improvement into the process $(\mathrm{x})$ balancing flow improvement with conversion improvement, and (xi) benchmarking. Therefore, it can be inferred from the above submissions that the overriding goal of lean thinking and production approach is basically the use of least effort and resources in achieving maximum value for the customer and minimizing all forms of wastes; and thus, it can be described as sustainable production approach.

Further, the literature reviewed also reveals that lean project delivery came into the construction industry through the work of [57] in which for the first time the possibility of adopting lean principles in construction to improve the industry's performance record in project delivery was presented. Since then there has been contending views on the implementation of lean principles in the construction industry. For instance, some authors $[16,69,86]: 156)$ posit that the main priority in the implementation of lean in the construction sector was the desire to meet costumers' expectations by eliminating waste in the planning, design and construction process. Other scholars (e.g. Refs. [1,31] are however insisting that the core issues in lean construction include waste reduction, a focus on production planning and control, end-user satisfaction, continuous improvements, cooperative relationships, and systems perspective. It was based on these submissions that Polesie (2010:1) and [54] argued that lean construction has a great potential in increasing efficiency, effectiveness and productivity in construction projects by minimizing non-value adding activities in all phases of project delivery. This means that lean construction is a departure from the traditional construction methods and seeks to promote the design of products concurrently with the process, maxmizing firm or professional performance for clients by adopting control measures that ensure that cost and time overruns are reduced to the barest minimuim and the desired performance quality are achieved in the lifecycle of construction projects.

\subsection{Lean construction practices (LCPs)}

In the existing literature [66,102]; Jamil and Fathi, 2016 [12]; are copious evidence showing that lean practices have been variously described as tools, techniques, concepts, approaches, and strategies that enable the attainment of lean construction goals. In other words, lean practices have been conceived of as the means through which lean philosophy/thinking is implemented at the planning, design and construction stages of projects as explained by Ref. [23]. In their view [93], explained that lean practices include a wide range of tools that can be used to enhance project management process, while studies $[66,67,98]$ noted that lean practices can either be implemented as integrated system or channel such as the lean project delivery system (LPDS) and the last planners system (LPS) or as stand-alone practices in construction projects.

Table 1 shows the list of LCPs identified from the articles reviewed. These lean practices were identified based on concrete evidence of their implementation at the various stages of planning, design, and construction of buildings and physical infrastructure projects in the different countries. 
Table 1

Lean construction practices (LCPs) identified in the literature.

\begin{tabular}{|c|c|c|}
\hline Lean Construction Practices & $\begin{array}{l}\text { Number of articles with } \\
\text { evidence of implemantation }\end{array}$ & Ranking \\
\hline Last Planner System (LPS) & 17 & 1 \\
\hline Just-in- time (JIT), & 10 & 2 \\
\hline Pull Scheduling/Planning & 8 & 3 \\
\hline Visualization tools/management & 7 & 4 \\
\hline Daily clustering/huddle meeting & 7 & 4 \\
\hline Concurrent Engineering (CE) & 7 & 4 \\
\hline Teamwork and partnering & 6 & 5 \\
\hline $\begin{array}{l}\text { Value Based Management/Value } \\
\text { Streaming Mapping (VBM/VSM) }\end{array}$ & 6 & 5 \\
\hline Total Quality Management (TQM) & 6 & 5 \\
\hline Virtual Design Construction (VDC) & 6 & 5 \\
\hline 5S Onsite Management & 5 & 6 \\
\hline $\begin{array}{l}\text { Plan of Conditions and Work } \\
\text { Environment or Environmental } \\
\text { Management System }\end{array}$ & 4 & 7 \\
\hline Kaizen & 4 & 7 \\
\hline $\begin{array}{l}\text { Total Production/Preventive } \\
\text { Maintenance (TPM) }\end{array}$ & 4 & 7 \\
\hline 6 Sigma & 3 & 8 \\
\hline Error Proofing (Poka-yoke) & 3 & 8 \\
\hline Conference Management (CM) & 2 & 9 \\
\hline $\begin{array}{l}\text { Health and Safety Improvement } \\
\text { Management }\end{array}$ & 2 & 9 \\
\hline Kanban System & 2 & 9 \\
\hline Standardization & 2 & 9 \\
\hline First Run Study & 2 & 9 \\
\hline Target Value Design (TVD) & 2 & 9 \\
\hline Gemba Walk & 2 & 9 \\
\hline Design Workshop or Big Room & 2 & 9 \\
\hline Prefabrication and Modularization & 2 & 9 \\
\hline Benchmarking & 2 & 9 \\
\hline $\begin{array}{l}\text { Location-Based Management System } \\
\quad \text { (LBMS) }\end{array}$ & 2 & 9 \\
\hline Work Structuring and Scheduling & 2 & 9 \\
\hline Fail Safe for Quality and Safety & 2 & 9 \\
\hline Design Structure Matrix (DSM) & 2 & 9 \\
\hline Detailed Briefing & 1 & 10 \\
\hline Integrated Project Delivery & 1 & 10 \\
\hline
\end{tabular}

Examination of the data in Table 1 will reveal that the most common LCPs identified in this review is the LPS, with its implementation reported in 17 different articles in the different countries (see Table 3 for the sources). The next to LPS is the JIT, reported in 10 different articles (see Table 4 for the sources). Other LCPs identified to have also been implemented are Pull Scheduling/Planning identified in eight articles (see Table 3 for the sources), concurrent engineering, visualization tools/management, and daily clustering/huddle meeting each with seven citations. The two least implemented LCPs identified are detailed briefing and integrated project delivery (IPD).

\subsection{Categories of lean construction practices}

Evidence in the literature [41] suggests that there are several categorisations of lean tools and techniques. Therefore, in an attempt to establish a basis for categorizing the identified 32 LCPs, a review of the existing classifications was done. An earlier work by Ref. [78] reveals that lean manufacturing tools and metrics have been categorised based on several parameters including, the level of abstraction in the tools, specific applications of the tools in the organization; the capacity of the tools to addresses management waste or activity waste; the type of resource waste the tools can address; and whether the tools can identify waste, measure waste, eliminate waste, or even serve these three functions simultaneously. As it relates to construction projects, authors $[7,58]$ have explained that based on the work by Glenn Ballard, the five key phases of the lean project delivery system in construction process are (i) project definition (specifications) (ii) lean design/planning (iii) lean supply (iv) lean assembly (construction), and (v) use.
Consequently, they insist that the categorization of lean parctices should be based on these phases of construction process. In the analysis of 685 papers published in the proceedings of the Annual Conference of the International Group for Lean Construction (IGLC) from 1993 to 2010 [33], also found that the categorization of lean construction tools has been based on the practices they can support in the construction process. Based on this, they identified the different categories of lean practices to include (i) design management and product development tools (ii) logistics and supply chain management tools (iii) human resources, multi-functionality and job autonomy tools (iv) information and communication technology (v) visual management and performance indicators standardized work tools (vi) layout and flow (vii) and continuous improvement tools. Others are tools for safety and sustainability pull production, continuous flow, cost control, and quality control.

In view of the foregoing and the fact that in the delivery of building and infrastructure projects, the key operations include design, planning, construction with management, control and monitoring being the key activities [15], the 32 LCPs identified have been categorised into four main groups based on areas of their possible implementation in the design, planning and construction of building and infrastructure projects. These four categories are (i) Design and Engineering practices (DEPs) (ii) Planning and Control Practices (PCPs) (iii) Construction and Site Management Practices (CMPs); and (iv) Health and Safety Management Practices (HSMPs). It is noteworthy that the classification developed in this article is not perfect as several of the LCPs can be put into more than one categories. This means that there is a significant overlap in the different categories identified in this review.

Tables (2-5) show the distribution of each of the 32 LCPs among the four categories and the various aspects and stages of planning, design and construction activities they can be implemented as identified in the literature. The first on the list of categories is the design and engineering practices (DEPs) displayed in Table 2. It is evident from Table 2 that the DEPs consist of nine different tools that help in achieving lean construction objectives at the design and fabrication stages of projects. Out of the practices categorised under this group, studies (see Ref. [7]; Picchi, 2016 [88]; have revealed that the virtual design construction (VDC) tools and the concurrent engineering appear to have been more implemented than others in the construction industry.

Table 3 is a display and description of the second category of LCPs identified from literature under the planning and control practices.

Examination of the contents in Table 3 shows that in the PCPs, there are nine lean practices that support among other activities strategic decision-making at the preconstruction, construction planning and control process. Among these include 6 Sigma, which is a quality control tool. From the number of articles that identified the tools in this category, it can be inferred that some of them are well implemented in the construction industry.

Table 4 presents the third category of LCPs described as construction and site management practices (CSMPs) with 11 tools/practices that promote proper management, organization and coordination of site activities and processes at the construction phase of project delivery.

The works cited in Table 4 reveal that some of the practices such as Just-in-time (JIT), total quality management (TQM), conference management (CM) and teamwork and partnering are more implemented than others like Gemba walk, Kanban system, and first run study.

Table 5 is also a display of practices categorised as health and safety management practices (HSMPs). This category of LCPs helps in achieving health and safety conditions for workers and equipment on construction sites. Table 5 shows detail description of the key components of this category of lean practices. Unlike the other three previously presented categories, this category of LCPs has only three practices identified under it as shown in Table 5. From the studies cited in Table 5, it can be inferred that among the three practices identified, fail safe for quality and safety appears to be the least implemented. 
Table 2

Design and engineering practices (DEPs).

\begin{tabular}{|c|c|c|}
\hline DEPs & Description & Sources \\
\hline Virtual Design construction (VDC) & $\begin{array}{l}\text { Design tool for creating computer aided designs (CAD) and simulations. It can also be used in testing for errors } \\
\text { in designs and models and direct transfer of error free design for production or prefabrication. }\end{array}$ & {$[7,32,37,87,88,96]$} \\
\hline Design structure matrix (DSM) & Used in structuring of design and design process into sequential segments & [51] \\
\hline Prefabrication and Modularization & $\begin{array}{l}\text { Prefabrication is used in the production project parts in an offsite factory which are moved to site for } \\
\text { installation. Modularization involves dividing spaces into equal repeated sections or modules of equal size to aid } \\
\text { the process of mass prefabrication of project components. }\end{array}$ & {$[43,88]$} \\
\hline Detailed briefing & This is pre-design tool enables proper analysis of clients brief and transference of the brief into design. & [11] \\
\hline Design workshops/big room workshop & $\begin{array}{l}\text { This is a room on site for meeting of project designers, where the entire design and its process are discussed and } \\
\text { analyzed to remove difficulties and suggest creative ideas for the design solutions. }\end{array}$ & {$[11,99]$} \\
\hline Integrated project delivery (IPD) & $\begin{array}{l}\text { Project delivery approach that involves signing of a contract between the client and key designers, contractors } \\
\text { and other stakeholders involved in the project. }\end{array}$ & {$[11,81]$} \\
\hline Target value design (TVD) & A design tool that ensures projects are designed based on clients set cost and time set targets. & {$[37,88]$} \\
\hline Standardization & $\begin{array}{l}\text { Standardization is the use of accepted dimensions, criteria and standards in the design of project component and } \\
\text { each operation involved in the project. }\end{array}$ & {$[7,35]$} \\
\hline Concurrent Engineering (CE) & $\begin{array}{l}\text { This involves collaborative sharing of information in the process of executing different task in a project with aim } \\
\text { of producing a functional design, a product with good quality and a productive process. }\end{array}$ & {$[7,12,51,61,74,77,88]$} \\
\hline
\end{tabular}

Table 3

Planning and control practices (PCPs).

\begin{tabular}{|c|c|c|}
\hline PCPs & Definition & Sources \\
\hline Last planner system (LPS) & $\begin{array}{l}\text { LPS is a planning and control improvement tool used for monitoring } \\
\text { construction process. It involves the use of master planning, phase planning, } \\
\text { looking-ahead planning and weekly planning. }\end{array}$ & {$[2,8,10,51,61,85,3,49,74,12,63,67,70,87,90,96,99]$} \\
\hline Work structuring and scheduling & $\begin{array}{l}\text { This is used in breaking down construction work process into separate and } \\
\text { sequential small parts in order to achieve reduction of work variability. }\end{array}$ & {$[7,70]$} \\
\hline $\begin{array}{l}\text { Location-based management system } \\
\text { (LBMS) }\end{array}$ & $\begin{array}{l}\text { This models the construction process into locations of activities and each module } \\
\text { is linked together based on their relationships }\end{array}$ & {$[90,99]$} \\
\hline Benchmarking & $\begin{array}{l}\text { Benchmarking involves dividing construction works into sections with } \\
\text { encouragement package attached to each section assigned to a team of workers } \\
\text { as a source of competition and motivation amongst project teams. }\end{array}$ & {$[11,51]$} \\
\hline 6 Sigma & $\begin{array}{l}\text { This helps to analyse the construction process (i.e. problem identification, } \\
\text { performance measurement, analyses of variations) from a statistical perspective } \\
\text { to achieve continuous improvement of the process. }\end{array}$ & {$[74,87,88]$} \\
\hline $\begin{array}{l}\text { Value based management (VBM) or } \\
\text { value stream mapping (VSM) }\end{array}$ & $\begin{array}{l}\text { This is a strategy used in mapping out non-value adding activities in the } \\
\text { construction process in order to maximize value and deliver it to the client of } \\
\text { costumer. }\end{array}$ & {$[7,32,70,74,84,87]$} \\
\hline Daily cluster or huddle meeting & $\begin{array}{l}\text { Daily cluster or huddle meeting involves the meeting of all site workers with the } \\
\text { projects management for discussing project issues, and thus helps in improving } \\
\text { communication between site workers and project managers. }\end{array}$ & {$[11,32,74,85,88,96]$} \\
\hline Pull Scheduling/planning & $\begin{array}{l}\text { This is the pulling together of materials in the entire value chain process to get } \\
\text { them ready on time for production according to project plan or schedule. }\end{array}$ & {$[7,11,37,63,70,74,96]$} \\
\hline Error proofing (Poka-yoke) & $\begin{array}{l}\text { This is used in checking the construction process ahead for errors, to avoid free } \\
\text { flow of errors into the construction process. }\end{array}$ & {$[7,72,85]$} \\
\hline
\end{tabular}

Table 4

Construction and site management practices (CSMPs).

\begin{tabular}{|c|c|c|}
\hline CSMPs & Description & Sources \\
\hline Gemba walk & It involves interrogating the source of a problem to uncover the cause of a problem, and fixing it. & {$[37,87]$} \\
\hline $\begin{array}{l}\text { Total productive/Preventive } \\
\text { maintenance (TPM) }\end{array}$ & $\begin{array}{l}\text { This is a hands-on preventive approach for maintaining site operator's equipment. This ensures that } \\
\text { operators take care of their equipment as they use it. }\end{array}$ & {$[7,74,84,88]$} \\
\hline Kanban system & $\begin{array}{l}\text { This is an ancient lean tool that involves the use of inventory control card or sign for stock taking on } \\
\text { project site. This helps to promote effective inventory and recording keeping on construction project } \\
\text { sites. }\end{array}$ & {$[74,88]$} \\
\hline 5s Onsite management & $\begin{array}{l}5 \mathrm{~S} \text { means sorting, straightening, shining, standardizing, and sustaining of all site processes and } \\
\text { activities with the aim of achieving good construction site management. }\end{array}$ & {$[7,51,61,73,74]$} \\
\hline First run study & $\begin{array}{l}\text { This is the modelling of important of construction site operations, especially when those involved } \\
\text { have little or no idea about the operation. It requires investigation of errors and alternative } \\
\text { approaches for preventing or mitigating them. }\end{array}$ & [74] \\
\hline Kaizen & This encourages continuous improvement in every construction site process. & {$[7,74,84,87]$} \\
\hline Teamwork and Partnering & $\begin{array}{l}\text { As the name implies, this involves collaboration between all stakeholders such as clients, designers, } \\
\text { planners, contractors, suppliers and others involved in the construction process. }\end{array}$ & {$[7,11,32,37,51,63]$} \\
\hline Total quality management (TQM) & $\begin{array}{l}\text { TQM is a construction management tool used to recognize and assess possible problems, develop and } \\
\text { apply new solutions and appraise results. }\end{array}$ & {$[11,51,74,61,68,88]$} \\
\hline Just-in-time (JIT) & $\begin{array}{l}\text { JIT enables prompt delivery of materials, information and drawings, or anything required for a } \\
\text { project to the point of usage. }\end{array}$ & {$[7,11,51,74,77,87,61,68,73,88]$} \\
\hline Visualization tools/management & $\begin{array}{l}\mathrm{VM} \text { is a tool used in passing specific instruction to workers on site. It might involve the use of sign } \\
\text { boards or posts in designated areas on construction sites. }\end{array}$ & {$[51,61,63,68,74,85,87,88]$} \\
\hline Conference Management (CM) & $\mathrm{CM}$ is a lean tool for coordinating conferences, workshops and trainings on a project. & {$[51,61]$} \\
\hline
\end{tabular}


Table 5

Health and safety management practices (HSMPs).

\begin{tabular}{|c|c|c|}
\hline HSMPs & Description & Sources \\
\hline Fail safe for quality and safety, & $\begin{array}{l}\text { It helps in minimizing harm on site, in some cases makes sure no employee is harmed on site at all by predicting } \\
\text { possible risk that my occur and taking proactive measure aimed at preventing it. }\end{array}$ & {$[74,85]$} \\
\hline $\begin{array}{l}\text { Plan of conditions and work environment or } \\
\text { ESM }\end{array}$ & $\begin{array}{l}\text { This lean strategy is useful in planning for safety and health through assessment, identification, and control of } \\
\text { likely risk. It usually involves planning of the entire safety of the workers and setting the conditions required for } \\
\text { achieving it. }\end{array}$ & {$[7,11,32,88]$} \\
\hline Health and Safety improvement management & This is an advanced lean tool that involves planning the health and safety conditions of site workers. & {$[32,71,88]$} \\
\hline
\end{tabular}

Regarding the stages in building and infrastructure procurement process LCPs have been implemented, analysis of the articles reviewed ( e.g. Refs. $[3,9,11,32,70,84,87,88,99]$ and [73] reveals that the construction stage has the most evidence of the implementation of lean practices. This is followed by planning and design, the operation and maintenance and then, the commissioning/handing over and demolition/renovation stages, respectively.

\subsection{Benefits of LCPs implementation}

The review also identified 20 benefits associated with the implementation of LCPs. The benefits identified in the literature were grouped into three categories relating to the sustainability goals. These are the economic, social and ecological (environmental) benefits as shown in Table 6. It is evident from Table 6 that most of the benefits associated with the implementation of LCPs are found within the economic and social domains with eight direct benefits each, and the least number found in the ecological (environmental) domain having only two benefits.

\section{Discussion}

From findings of this review, three key issues were considered important for further discussion. The first issue deals with the number of LCPs identified in the research literature. Although in their study on classification scheme for lean manufacturing tools [78], identified 101 lean manufacturing tools, this review was able to identify 32 different lean practices or tools that have been implemented in the construction sector as reported in research literature. This difference in the number of lean practices identified in the manufacturing sector and construction industry is understandable and did not come as a surprise. This is because the lean production approach originated and was initially implemented in the automobile manufacturing industry in the 1950s
$[18,19,46]$, but it was adopted in the construction industry over three decades later [17,60]; Jamil and Fathi, 2016). Therefore, as the originator and earliest adopter of lean production practices, the manufacturing sector is naturally expected to be ahead of other sectors in terms of the number and level of implementation of lean practices and tools. Another possible reason for the difference is the fragmented and project-based nature of the construction industry, which authors [42,59] have argued is responsible for the slow pace of adoption of innovation such as lean principles and practices. In any case, one key inference from this particular finding is that although there are several lean tools, practices, techniques and principles implemented in the manufacturing sector, many of them have also been implemented while most are yet to be adopted in the construction industry. This suggests that the implementation of lean principles and practices in the construction industry is still evolving and yet to reach a maturity level when compared to the manufacturing sector.

The result also reveals that among the 32 LCPs identified in the research literature, the last planner system (LPS) is the most implemented. Notably, the LPS comprises majorly lean construction planning principles that enable smooth planning of projects; and thus it can serve as both a lean construction tool and lean construction application channel. Maru (2017) noted that LPS is an integral part of a new production management system for one-off project-based production like design and construction and allows project managers to significantly improve productivity and client/end-user satisfaction. In addition [102], described LPS as a powerful technique managers engage in planning strategies and operations and in preparing work schedules, which engenders the creation of new explicit knowledge in a project. Hence, it is considered a veritable planning and control improvement tool used for comprehensive planning and monitoring of construction process.

Notably, there is the consensus among authors cited in Table 3 that LPS is the most established and adopted lean construction practices

Table 6

Benefits associated with the adoption of lean construction practices.

\begin{tabular}{|c|c|c|}
\hline Category of benefits & Benefits in each group & Sources \\
\hline \multirow[t]{9}{*}{ Economic (cost, quality and time) } & Reduction in project time/schedule & {$[3,7,9,11,13,32,43,49,63,88,99]$} \\
\hline & Reduction of project cost & {$[3,7,10,11,14,43,73,74]$} \\
\hline & Improvement of project quality & {$[7,11,13,63,74,88,43]$} \\
\hline & Continuous Improvement of process & {$[3,13,74,88]$} \\
\hline & More inventory control & {$[88,73]$} \\
\hline & Increment in market share & [88] \\
\hline & Risk minimization & [14] [49] \\
\hline & Decrease in variability of work flow & {$[3,9,32]$} \\
\hline & Improvement in project delivery method & [14] \\
\hline \multirow[t]{9}{*}{ Social (relationship and people satisfaction) } & Work efficiency increment/increased labour productivity and performance & {$[9,13,61,68,70,74,88,99,103]$} \\
\hline & Generation of better value for client/customer satisfaction & {$[13,14,74,88]$} \\
\hline & Employee satisfaction & {$[11,63,74,88]$} \\
\hline & Improved health and safety & {$[11,73,74,88][43]$} \\
\hline & Improved suppliers relationship & [88] \\
\hline & Achievement of reliability, accountability, certainty (predictability) and honesty on projects & {$[3,9,14,63,74,99]$} \\
\hline & Better cooperation among stakeholders & {$[11,63,74]$} \\
\hline & Improvement of management and control & [9] \\
\hline & Better coordination & {$[9,99]$} \\
\hline \multirow[t]{2}{*}{ Environmental } & Reduction of project waste & {$[13,14,43,61,63,68,74,84,94]$} \\
\hline & Attainment of green construction & {$[13,30,40,52,61,63,74]$} \\
\hline
\end{tabular}


because it involves the use of different kinds of planning approaches such as master planning, phase planning, look ahead planning and weekly planning to achieve proper planning and scheduling of activities both at the design and construction stages of projects, which make it very suitable for the construction industry. Furthermore, some authors $[3,15][49]$; have also explained that LPS has been widely implemented in the construction industry because its effectiveness can be measured by increment in the percentage of plan completed (PPC) or reduction in the percent expected time overun (PET) on projects. This view was corroborated by Ref. [85] who also observed that the level of implementation of LPS in construction was high because together with other lean practices identified under the lean planning and control practices in Table 3, they have established measuring and monitoring parameters and criteria; hence, it is very easy to assess and monitor their implementation in construction projects.

Next to LPS in terms of adoption is the Just-in- time (JIT). According to [39]; JIT is one of the original two pillars of lean production and it enables prompt delivery of materials, information, equipment, drawings and other inputs required in a project to the point they are required. JIT has also been described as one the common lean construction and site management and environmentally-friendly practice that has been implemented as part of the traditional construction practices $[4,61,88]$. One possible reason for the identification of the LPS and JIT as the two most implemented LCPs is that both contribute to achieving one of the goals of lean production approach, which is the reduction in the timeline of projects. In fact, from the descriptions of these practices as presented in Tables 3 and 4 it is obvious that both LPS and JIT help in the reduction of the turnaround time of activities leading to minimizing the possibility of interruption of process, cost and time overruns in construction project delivery.

The second issue emanating from findings of this review deals with the different categories of lean practices and stages of construction projects they have been implemented. From the results presented in Tables (2-5) four categories of LCPs: (i) design and engineering practices(DEPs) (ii) planning and control practices (PCPs) (iii) construction and site management pratices (CMPs); and (iv) health and safety management practices (HSMPs) were identified. A critical analysis of these four categorises revealed that they appear to be very relevant to management methods for achieving lean principles, and most of them seek to address key economic (e.g. cost and time overruns) and social (quality improvement and client/end-user satisfaction) related issues in construction projects delivery. However, a closer examination of the categories will reveal that there are also some environmental relevant leans practices such as the virtual design and construction; prefabrication and modularization and Just-in-time that have been implemented in the construction industry. Specifically, the virtual design and construction, which is part of the design and engineering practices is based on the use of computer aided design and drafting (CAAD), Building Information Modelling (BIM) and information technologies for design, drafting, 3D modelling and fabrication. Some authors $[4,37,59,88]$ have identified the role virtual design and construction plays in promoting green construction by integrating technology, process and people involved in the design, tendering and construction phases of construction projects in a virtual environment and reducing the level of paperwork, travelling and energy consumption required in construction procurement process. In fact [72], explained that the adoption of virtual design and construction method brings positive benefits to the environment by reducing the level of dependency on fossil fuel and paperwork right from the planning and design to construction, operation, maintenance and demolition phases of projects resulting in the production of energy efficient buildings.

Another environmental relevant lean practice identified under the design and engineering practices is prefabrication and modularization $[43,88]$. There is a consensus among authors [4,50,52] that prefabrication and modularization encourage the manufacturing of construction components off site; and thus help to reduce the level of noise and air pollution and other harmful effects construction activities have on the immediate and surrounding environment. This is because prefabrication can contribute to eliminating adverse effects on the environment as a result of the movement of workers, machines, materials, erecting of temporary structures and other activities linked the production of components on site. In addition, prefabrication and modularization are also known to promote recycling of materials in an offsite environment, which also reduces harmful defects this could have on the ecological environment when such materials are disposed off as waste. From the construction and site management pratices (CMPs) is another environmentally revelant lean practice known as the Just-intime (JIT). There is evidence in the literature $[4,61,88]$ suggesting that JIT is one of the environmentally-friendly lean supply practices because it can help to reduce damage and materials waste and unwarranted movement of vehicles and equipment resulting from untimely supply of materials and other inputs during the construction phase of projects. These lean practices, according authors $[6,83]$, contribute to promoting the environmental sustainability rating of construction activities.

Further analysis of the four categories of LCPs identified in this review shows that the lean construction and site management practices have the highest number with 11 lean tools, followed by the lean planning and control practices, and lean design and engineering practices with nine tools each. The category with the least number of tools is lean health and safety management practices with three tools. Examination of the individual tools reveals that in Table 4, the JIT and visualization tools/management appear to be the two most implemented lean construction and site management practices as they have the highest number of articles linked to them. This is probably because both practices do not require special skill for their implementation compared to the other nine practices in this group. For the lean planning and control practices, the most adopted is the LPS. The features and benefits of LPS that engender its implementation in construction have already been previously discussed in this paper (see also [85,102].

In addition, among the nine tools identified in the lean design and engineering practices, virtual design construction (VDC) and concurrent engineering (CE) emerged as the top two most implemented LCPs. From of the descriptions of these two tools as presented in Table 3 it is evident that these tools tend to promote collaborative work, which helps to reduce the turnaround time for activities and minimize errors in the entire project delivery process $[37,88]$. These might help to explain why they are the most implemented lean design and engineering practices in the construction industry. For the lean health and safety management practices, it is evident in Table 5 that plan of conditions and work environment which deals with comprehensive assessment, identification, planning and controlling of the safety of the workers on site emerged as the most implemented of three tools identified in this category. According to authors $[85,88]$, this is because comprehensive identification and assessment of risk factors, planning and implementing mitigating strategies are vital to ensuring health and safety of workers and equipment on construction sites.

In all, the review found that the construction stage appears have witnessed the highest level of implementation of LCPs than any other stage construction project life cycle. In fact, this result supports the findings by Ref. [88] in Saudi Arabia, where the construction phase was identified as the phase where LCPs was most implemented in that country. One of the possible explanation for this is that the construction phase of building and infrastructure projects is one of the most critical stages and it involves a wide range of participants rainging from professional consultants to contactors, trademens, suppliers, regulatory bodies and unskilled workmen. This makes it to be more prone to nonvalue adding activities, failure to meet timelines, and material waste than any other stage, leading to time and cost overuns and poor quality deliverables. Therefore, in attempt to minimize the possibility of these undesirable events at the construction stage, several lean practices are implemented to ensure that the desired project outcomes are achieved 
with minimuim efforts.

The third issue worthy of discussion here is concerned with the benefits of implementation of LCPs in achieving the overall sustainability agenda. Findings from several studies reviewed (e.g. Refs. $[20,27,71,30,82,86,95]$; reveal that several milestones have been achieved in the implementation of LCPs with attendant benefits in the different countries. In support of this, the data in Table 6 shows that the main benefits of LCPs can be grouped into economic, social and environmental benefits, which represent the three main domains of the sustainability agenda [54]. From this review, it was found that some of the specific benefits associated with the implementation of LCPs that are consistent with the sustainability agenda include the reduction of project time, waste and cost, increased labour productivity and performance, improvement of projects quality and achievement of reliability, accountability, honesty and client/end-user satisfaction. These are very relevant to the attainment of economic [64] and social $[13,74,88]$ sustainability goals. They also underscore the key essence of lean production approach, which is to minimize waste and optimize product quality for the customer/end-users satisfaction [7,58,80,88]. On the one hand most of the leans practices identified in Tables (2-5) are relevant management practices that seek to check the growing incidence of cost and time overruns in construction projects. The need to optimize product quality and improves client and end-users satisfaction with construction projects on the other hand informs the inclusion of quality management tools such as total quality management (TQM) $[61,68]$ and 6 Sigma $[74,87,88]$; value based management (VBM) or value stream mapping (VSM) [70], concurrent engineering [12,88] and others in the list of LCPs that bring social benefits.

In addition to the social and economic benefits of the implementation of LCPs, the review also found that LCPs have made contributions to a reduction in material wastes, which several studies $[26,28,47,75]$ have explained are injurious to the ecosystem. Added to this, the review has highlighted the relevance of lean construction practices such as the virtual design and construction; prefabrication and modularization and Just-in-time in promoting environmental sustainability. In fact, these practices have been acknowledged by several authors $[4,12,36,50,54,56,66]$ as the key channels through which lean implementation in construction can contribute to mitigating the adverse impacts of construction activities on the physical environment. This suggests that the implementation of lean practices has the potential to significantly change the negative perception of the construction activities as major contributors to environmental degradation.

\section{Conclusions}

This article has identified, categorised and analyzed the different lean practices implemented in the construction industry and their benefits in the sustainability agenda through a systematic review of literature. Based on the findings, the following conclusions are made. First, at least, 32 different lean practices have implementated in the construction industry with the last planner system (LPS) and just-intime (JIT) being the most documented practices in the industry globally. Second, the identified LCPs can be categorised into four major groups based on their implementation at the planning, design, construction stages of building and infrastructure projects with many of them found relevant in addressing economic and social issues but very few found to be environmentally relevant. Third, at least 20 different benefits, grouped under economic, social and environmental domians can be derived from the implementation of lean parctices in construction.

Findings of this review are very instructive in showing that based on the growing volume of literature on lean construction, the construction industry is making progress in improving its productivity and sustainability profiles through the implementation of the lean production approach. However, when compared to the manufacturing sector in terms of the number of lean practice implemented so far, the construction industry appears to be lagging behind the manufacturing sector. Again, from this review is the finding that there is an established culture in the implementation of last planner system (LPS), just-in-time (JIT) and Pull Scheduling/Planning aspects of lean production in the construction. Arguably, this suggests that these three practices can easily be implemented by all categories of firms in the industry. In addition, it also suggests that there are significant barriers in the implementation of a high percentage of the 32 LCPs in the construction industry.

Furthermore, from the review is evidence that the lean practices implemented in the construction industry are mostly management practices that seeks to address cost and time overruns (economic issues) and enhance the quality of construction projects and client/end-user satisfaction (social issues), but very few are environmentally relevant. This notwithstanding, the review implies that LCPs have great potentials in contributing to the attainment of economic, social, and ecological goals of construction projects by helping to mitigate the adverse impacts of construction activities on the social, economic and ecological environment. In the light of the foregoing, it is recommended that further research be carried out to uncover reasons for the low implementation of several LCPs and how the benefits of implementation of LCPs can be maximized in construction project delivery and in building a sustainable built environment.

\section{References}

[1] T.S. Abdelhamid, M. El-Gafy, O. Salem, Lean construction: fundamentals and principles, American Professional Constructor Journal 4 (2008) 8-19.

[2] S. Adamu, G.A. Howell, R. Abdul Hamid, Lean construction techniques implementation in Nigeria Construction Industry, Int. J. Sci. Eng. Res. 3 (12) (2012) $1-11$.

[3] O. Ahiakwo, D. Oloke, S. Suresh, J. Khatib, A case study of last planner system implementation in Nigeria, 21st Annual Conference of the International Group for Lean Construction, IGLC, Fortaleza, Brazil, 2013, pp. 699-707.

[4] R. Ahuja, Lean and green construction, Int. J. Sci. Eng. Res. 3 (7) (2012) 1-4.

[5] S.O. Ajayi, L.O. Oyedele, M. Bilal, O.O. Akinade, H.A. Alaka, H.A. Owolabi, K.O. Kadiri, Waste effectiveness of the construction industry: understanding the impediments and requisites for improvement, Resour. Conserv. Recycl. 102 (2015) 101-112.

[6] S.O. Ajayi, O.L. Oyedele, O.O. Akinade, B. Muhammad, H.A. Alaka, H.A. Owolabi, K.O. Kadiri, Attributes of design for construction waste minimization: a case study of waste-to-energy projects, Renew. Sustain. Energy Rev. 73 (2017) 1333-1341.

[7] R. Al-Aomar, Analysis of lean construction practices at abu dhabi construction industry, Lean Constr. J. (2012) 105-121.

[8] L.F. Alarcon, S. Diethelmand, S. Rojo, Collaborative implementation of lean planning systems in chilean construction companies, 10th Annual Conference for the International Group for Lean Construction, International Group for Lean Construction, Gramado, Brazil, 2002, pp. 1-11.

[9] L.F. Alarcon, S. Diethelmand, S. Rojo, R. Calderon, Assessing the impacts of implementating lean construction, 14th Annual Conference of the International Group for Lean Construction, International Group for Lean Construction, Santiago, Chile, 2006, pp. 26-33.

[10] A. Alsehaimi, P. Tzortzopoulos, L. Kosela, Last planner system: experiences from pilot implementation in the Middle East, 17th Annual Conference of the International Group for Lean Construction, International Group for Lean Construction, Taipei, Taiwan, 2009, pp. 53-66.

[11] B. Andersen, A.M. Belay, E.M. Seim, Lean construction practices and its effects: a case at St Olav's integrated hospital, Norway, Lean Constr. J. (2012) 122-149.

[12] R.H. Ansah, S. Sorooshian, Effect of lean tools to Control external environment risks of construction projects, Sustainable Cities and Society 32 (2017) 348-356.

[13] T.M. Ayalew, Z.M. Dakhli, Z. Lafhaj, The future of lean construction in ethiopian construction industry, Int. J. Eng. Res. Technol. 5 (02) (2016) 107-113.

[14] J. Ayarkwa, K. Agyekum, E. Adinyira, D. Osei-Asibey, Perspectives for the implementation of lean construction in the ghanian construction industry, Journal of Construction Project Management and Innovation 2 (2) (2012) 345-359.

[15] R.F. Aziz, S.F. Hafez, Applying lean thinking in construction and performance improvement, Alexandria Engineering Journal 52 (2013) 679-692.

[16] J. Bae, Y. Kim, Sustainable value in construction projects and lean construction, Journal of Green Building 3 (1) (2008) 156-167.

[17] G. Ballard, The Lean Delivery System as a Strategy for Adding Value in Construction Projects, SIBRAGEC, Campinas, Brazil, 2007 October 2007.

[18] G. Ballard, Lean delivery system: an update, Lean Constr. J. 2008 (2008) 1-9.

[19] G. Ballard, G. Howell, Implementing Lean Construction: Understanding and Action". IGLC-6, UFRGS, Guarujá, Brazil, 1998.

[20] A. Björnfot, L. Bildsten, J. Erikshammar, M. Haller, P. Simonsson, Lessons learned from successful value stream mapping (VSM), 19th Annual Conference of the International Group for Lean Construction, International Groups for Lean Construction, Lima, Peru, 2011, pp. 163-173.

[21] S. Cano, J. Delgado, L. Botero, O. Rubiano, Barriers and success factors in lean 
construction implementation - Survey in pilot context, 23rd Annual Conference of the International Groups for Lean Construction, International Groups for Lean Construction, Perth, Australia, 2015, pp. 631-641.

[22] K.J. Cheng, A.O. Mydin, Best Practices of Construction Waste Management and Minimization vol. XXI, Analele Universitatii"Eftimie Murgu" Resita Anul, 2014, pp. 72-84 NR 1.

[23] Constructing Excellence, Lean Construction: Innovation, Best Practice and Productivity, Constructing Excellence, 2004.

[24] P. Dallasega, E. Rauch, M. Frosolini, A lean approach for real-time planning and monitoring in engineer-to-Order construction projects, Buildings 38 (8) (2018) $1-22$.

[25] M.P. Devaki, R. Jayanthi, Barriers to implementation of lean principles in the Indian construction industry, Int. J. Eng. Res. Technol. 3 (5) (2014) 1189-1193.

[26] W. Dixon, The Impacts of Construction and the Built Environment, WD ReThinking Ltd, UK, 2010.

[27] M.F. Dulami, C. Tanamas, The principles and application of lean construction in Singapore, 9th Annual Conference of the International Group for Lean Construction, International Group for Lean Construction, Singapore, 2001, pp. $1-14$.

[28] A.I. Edoka, A.J. Richard, O.A. Bamidele, B.A. Abuldulquadri, An assessment of environmental impacts of building construction projects, Civ. Environ. Res. 3 (1) (2013) 93-106.

[29] F. Emuze, Qualitative content analysis from the lean construction perspective: a focus on supply chain management, Acta Structilia 19 (1) (2012) 1-18.

[30] F. Emuze, J. Smallwood, The integration of Health and Safety (H\&S), lean and sustainability in Construction: a literature review, Proceedings IGLC-21, July 2013 | Fortaleza, Brazil, 2013, pp. 853-862.

[31] P.E. Eriksson, Improving construction supply chain collaboration and performance: a lean construction pilot project, Supply Chain Manag.: Int. J. 15 (5) (2010) 394-403.

[32] H. Erol, I. Dikmen, T.M. Birgonul, Measuring the impact of lean construction practices on project duration and variability : a simulation-based study on residential buildings, J. Civ. Eng. Manag. 23 (2) (2016) 241-251.

[33] B.M.B.S. Etges, T.A. Saurin, I.R. Bulhões, Identifying lean construction categories of practices in IGLC proceedings, Proceedings for the 20th Annual Conference of the International Group for Lean Construction, 2012 Retrieved from https:// www.researchgate.net/publication/289632776 Identifying lean_construction categories_of_practices_in_IGLC_proceedings on 5th May, 2018.

[34] M.E. Falagas, E.I. Pitsouni, G.A. Malietzis, G. Pappas, Comparison of PubMed, Scopus, web of science, and Google scholar: Strengths and weaknesses, Faseb. J. 22 (2008) 338-342.

[35] N.B.L.S. Fernandes, C.P. Valente, A.B. Saggin, F.L. Brito, C.A.M.A. Mourao, S.J.B. Elias, Proposal for the structure of a Standardization manual for lean tools and processes in a construction site, 24th Annual Conference of the International Group for Lean Construction, International Group for Lean Construction, Boston, 2016, pp. 103-112.

[36] J.L. Fernandez-Solis, V. Porwal, S. Lavy, A. Shafaat, Z.K. Rybkowski, K. Son, Survey of motivations, benefits, and implementation challenges of last planner system users, J. Construct. Eng. Manag. 139 (4) (2016) 354-360.

[37] J.V. Franco, F.A. Picchi, Lean design in building projects: guiding principles and exploratory collection of good practices, 24th Annual Conference of the International Groups for Lean Construction. Section 4, International Groups for lean Construction, Boston, MA, USA, 2016, pp. 113-122.

[38] S. Green, Systematic review and meta-analysis, Singap. Med. J. 46 (6) (2005) 270-274.

[39] S.D. Green, Making Sense of Construction Improvement, Wiley-Blackwell, Chichester, 2011.

[40] C.P. Gomez, A. Raut, A.U. Raji, Generating value at preconstruction: minding the gap in lean architectural practices, 23rd Annual Conference of the International Group for Lean Construction, IGLC, Perth, Australia, 2015, pp. 846-855.

[41] N.B.M. Hame, T.O. Kowang, G.C. Fei, Categorization of lean research and development tools and techniques: a process-based approach, Indian Journal of Science and Technology 10 (3) (2017) 1-7.

[42] M. Hardie, G. Newell, Factors influencing technical innovation in construction SMEs: and Australian perspective, Eng. Construct. Architect. Manag. 18 (6) (2011) 618-636.

[43] M. Hermes, Prefabrication \& modularization as a part of lean construction - Status quo in Germany, 23rd Annual Conference of the International Group for Lean Construction, IGLC, Perth, Australia, 2015, pp. 235-245.

[44] M. Hook, L. Stehn, Lean practices in industralized housing production: the need for a cultural change, Lean Constr. J. (2008) 20-33.

[45] G.A. Howell, What Is Lean Construction? Proceeding Seventh Annual Conference of International Group of Lean Construction, IGLC-7, University Of California, Berkeley, CA, USA, 1999.

[46] G. Howell, T. Abdelhamid, Lean Construction Frequently Asked Questions, Lean Construction Institute, 2012.

[47] J.D. Hussin, I.A. Rahman, A.H. Memon, The way forward in sustainable construction: issues and challenges, Int. J. Adv. Appl. Sci. (2013) 15-24.

[48] N.H. Ibrahim, Reviewing the evidence: use of digital collaboration technologies in major building and infrastructure projects, J. Inf. Technol. Construct. 18 (2013) 40-63.

[49] U. Issa, Implementation of lean construction techniques for minimizing the risks effect on project construction time, Alexandria Engineering Journal 52 (2013) 697-704.

[50] L. Jallon, C.S. Poon, Y.H. Chiang, Quantifying the waste reduction potential of using prefabriction in building construction in Hong Kong, Waste Manag. 29
(2009) 309-320.

[51] E. Johansen, L. Walter, Lean construction: prospects for the German construction industry, Lean Constr. J. 3 (1) (2007) 19-32.

[52] C.A. Johnsen, F. Drevland, Lean and sustainability: three pillar THinking in the production process, 24th Annual Conference of the International Group for Lean Construction, IGLC, Boston, MA, USA, 2016, pp. 23-32.

[53] K.S. Khnan, R. Kunz, J. Kleijnen, G. Antes, Five steps to conducting a systematic review, J. R. Soc. Med. 96 (2003) 118-121.

[54] L.M. Khodeir, R. Othman, Examining the interaction between lean and Sustainability principles in the management process of AEC Industry, Ain Shams Engineering Journal (2016) Retrieved on 12 November, 2017 from https://doi. org/10.1016/j.asej.2016.12.005.

[55] C. Ko, Lean building design model, 7th international conference on engineering, project, and production management, Procedia Engineering 182 (2017) 329-334.

[56] C. Koranda, W.K. Chong, C. Kim, J.-S. Chou, C. Kim, An investigation of the applicability of sustainability and lean concepts to small construction projects, KSCE Journal of Civil Engineering 16 (5) (2012) 699-707.

[57] L. Koskela, Application of New Production Philosophy to Construction. CIFE Technical Report No. 72, Stanford University, CA, 1992, pp. 15-17 citeseerx.ist.psu.edu/viewdoc/download?doi $=10.1 .1 .15 .9598 \&$ rep $=$ rep $1 \ldots$ pdf Retrieved on, Accessed date: 17 May 2018.

[58] Z.E. Kpamma, T. Adjei-kumi, The lean project delivery system (LPDS): application at the design and documentation stage of building construction process in Ghana, in: S.L. Laryea (Ed.), West Africa Built Environment Research Conference, WABER, Accra, Ghana, 2010, pp. 597-604.

[59] S. Laryea, E.O. Ibem, Patterns of Technological Innovation in the use of eProcurement in Construction, J. Inf. Technol. Construct. 19 (2014) 104-125.

[60] Lean Construction Institute, What is lean construction? Retrieved 13 February 2018 from, 2012. http://www.leanconstruction.org.

[61] S. Li, X. Wu, Y. Zhou, X. Liu, A study on the evaluation of implementation level of lean construction in two Chinese firms, Renew. Sustain. Energy Rev. 71 (2017) 846-851 https://doi.org/10.1016/j.rser.2016.12.112.

[62] V.L.J. Lim, Lean Construction: Knowledge and Barriers in Implementing into Malaysia Construction Industry, (2008) from http://eprints.utm.my , Accessed date: 26 August 2011

[63] D. Limon, Measuring Lean Construction: a Performance Measurement Model Supporting The Implementation Of Lean Practices In the Norwegian Construction Industry. Deoartment of Production and Quality Engineering, Norwegian University of Science and Technology, Norway, 2015.

[64] P.E.D. Love, Influence of project type and procurement method on rework costs in building construction projects, ASCE Journal of Construction Engineering and Management 128 (1) (2002) 18-29.

[65] W. Lu, H. Yuan, A framework for understanding waste management studies in construction, Waste Manag. 31 (6) (2011) 1252-1260.

[66] M.A. Marhani, A. Jaapar, N.A.A. Bari, M. Zawawi, Sustainability through lean construction approach: a literature review, Procedia - Social and Behavioral Sciences 101 (2013) 90-99.

[67] A.A. Maru, Lean construction in civil engineering and project management: case study analysis of UT arlington college park, Am. J. Civ. Eng. 3 (3) (2015) 70-74.

[68] M. Minas, A Framework for Improving Construction Project Performance in Ethiopia Using Ean Construction. Addis Ababa University, Department of Science in Industrial Engineering, Addis Ababa University, Addis Ababa, Ethiopia, 2016.

[69] J.M. Morgan, J.F. Liker, The Toyota Product Development System, Productivity Press, New York, USA, 2006.

[70] D. Murguia, X. Brioso, A. Pimentel, Applying lean techniques to improve performance in the finishing phase of a residential building, 24th Annual Conference of the International Group for Lean Construction, IGLC, Boston, Ma, USA, 2016, pp. 43-52.

[71] I. Nahmens, L.H. Ikuma, An empirical examination of the relationship between lean construction and safety in the industrialized industry, Lean Constr. J. 2009 (2009) 1-12.

[72] A. Nikakhtar, A.A. Hosseini, K.Y. Wong, A. Zavichi, Application of lean construction principles to reduce construction process waste using computer simulation: a case study', Int. J. Serv. Oper. Manag. 20 (4) (2015) 461-480.

[73] P. Nowotarski, J. Paslawski, J. Matyja, Improving construction processes using lean management methodologies - cost case study, Procedia Engineering 161 (2016) 1037-1042.

[74] O. Ogunbiyi, Implementation of the Lean Approach in Sustainable Construction: Conceptual Framework. Grenfell-baines School of Architecture, Construction and Environment, University of Central Lancashire, Lancashire, UK, 2014.

[75] E. Ola-adisa, Y.C. Sati, I.I. Ojonigwa, An architectural approach to Solid waste management on selected building construction sites in bauchi, International Journal of Emerging Engineering Research and Technology 3 (12) (2015) 67-77.

[76] A.L. Olanrewaju, A.R. Abul-aziz, An Overview of the construction industry, in: A a.-a. Olanrewaju (Ed.), Building Maintenance Processes and Practices: the Case of a Fast Developing Country, Springer, Singapore, 2015, pp. 9-34.

[77] J. Olatunji, Lean-in-Nigerian Construction: State, Barriers, Strategies and "go-togemba" Approach. International Group of Lean Construction, International Group of Lean Construction, Manchester, UK, 2008, pp. 14-20.

[78] S.J. Pavnaskar, J.K. Gershenson, A.B. Jambekar, Classification scheme for Lean manufacturing tools, Int. J. Prod. Res. 41 (13) (2003) 3075-3090.

[79] L. Pinch, Lean construction, Construction Executive 15 (11) (2005) 8-11.

[80] P. Polesie, Lean Constriction Philosophy and Individual Freedom, Proceedings IGLC-18, Technion, Haifa, Israel, 2010, pp. 376-385 July 2010.

[81] F. Riached, Y. Hraoul, A. Karam, F. Hamzeh, Implementation of IPD in the Middle East and its challenges, 22nd Annual Conference of the International Groups for 
Lean Construction, International Groups for Lean Construction, Oslo, Norway, 2014, pp. 293-304.

[82] L. Rubrich, An Introduction to Lean Construction: Applying Lean to Construction Organizations and Processes, WCM Associates, Fort Wayne, 2012.

[83] P. Saieg, E.D. Sotelino, D. Nascimento, R.G.G. Caiado, Interactions of building information modeling, lean and sustainability on the architectural, engineering and construction industry: a systematic review, J. Clean. Prod. 174 (2018) 788-806.

[84] F.E. Sakka, K. Fid, T. Narciss, F. Hamzeh, Integrating lean into modular construction: a detailed case study of Company X, 24th Annual Conference of the International Group for Lean Construction, IGLC, Boston, MA, USA, 2016, pp. 23-32.

[85] O. Salem, J. Solomon, A. Genaidy, M. Luegring, Site implementation and assessment of lean construction techniques, Lean Constr. J. 2 (2) (2005) 1-59.

[86] O. Salem, J. Solomon, A. Genaidy, I. Minkarah, Lean construction: from theory to Implementation, J. Manag. Eng. 22 (4) (2006) 168-175.

[87] J.L. Salvatirerra, L.F. Alarcon, A. Lopez, X. Valasquez, Lean diagnosis for chilean construction industry: towards more sustainable lean practices, 23rd Annual Conference of the International Group for Lean Construction, International Group for Lean Construction, Perth, Australia, 2015, pp. 642-651.

[88] J.G. Sarhan, S. Fawzia, A. Karim, Lean construction implementation in the Saudi arabian construction industry, Construction Economics and Building 17 (1) (2017) 46-69.

[89] J. Sarhan, B. Xia, S. Fawzia, A. Karim, A. Olanipekun, Barriers to implementing lean construction practices in the kingdom of Saudi Arabia (KSA) construction industry, Construct. Innovat. 18 (2) (2018) 246-272.

[90] O. Seppanem, R. Modrich, G. Ballard, Integration of last planner system and location-based management system, 23rd Annual Conference of the International Groups for Lean Construction, International Groups for Lean Construction, Perth, Autralia, 2015, pp. 123-132.

[91] E.P. Small, K. Al Hamouri, H. Al Hamouri, Examination of Opportunities for integration of lean principles in construction in dubai, Procedia Engineering 196 (2017) 616-621.
[92] J. Smith, A case study on design science research as a methodology for developing tools to support lean construction efforts, 23rd Annual Conference of the International Group for Lean Construction, IGLC, Perth, Australia, 2015, pp. $517-526$.

[93] M. Tauriainen, P. Marttinen, B. Davea, L. Koskela, The effects of BIM and lean construction on design management practices, Procedia Engineering 164 (2016) $567-574$.

[94] A. Tezel, Y. Nielsen, Lean construction conformance among construction contractors in Turkey, J. Manag. Eng. 29 (3) (2013) 236-250.

[95] A. Tezel, L. Koskela, Z. Aziz, Current condition and future directions for lean construction in highways projects: a small and medium-sized enterprises (SMEs) perspective, Int. J. Proj. Manag. 36 (2018) 267-286.

[96] P. Tillmann, D. Viana, Z. Sargent, I. Tommelein, C. Formoso, Bim and leean in the design-production interface of ETO components in complex projects, 23rd Annual Conference of the International Group for Lean Construction, IGLC, Perth, Australia, 2015, pp. 331-340.

[97] I. Tommelein, Journey towards lean construction: pursuing a paradigm Shift in the AEC industry, J. Construct. Eng. Manag. 141 (6) (2015) 1-12 https://doi.org/10. 1061/(ASCE)CO.1943-7862.0000926.

[98] S.J. Tuholski, I. Tommelein, Design structure matrix implementation on a Seismic retrofit, J. Manag. Eng. 26 (3) (2010) 144-15.

[99] K. Vaidyanathan, S. Mohanbabu, P. Sriram, S. Rahman, S. Arunkumar, Application of lean principles to managing construction of an IT commercial facility - an indian experience, 24th Annual Conference of the International Group for Lean Construction, International Group for Lean Construction, Buston, MA, USA, 2016, pp. 183-192.

[101] J. Womack, D. Jones, Lean Thinking, Simon \& Schuster, New York, 1996.

[102] L. Zhang, X. Chen, Role of lean tools in supporting knowledge creation and performance in lean construction, Procedia Engineering 145 (2016) 1267-1274.

[103] X. Zhang, S. Azhar, A. Nadeem, M. Khalfan, Using building information modelling to achieve lean principles by improving the efficiency of work team, International Journal of Construction Management 18 (4) (2018) 293-300. 